\title{
ANC adviser takes over at science ministry
}

Cape Town. Roger Jardine, for the past three years the leading science policy adviser to the African National Congress (ANC), has been appointed director-general of South Africa's Department of Arts, Culture, Science and Technology, the ministry responsible for the government-funded research councils.

A radiological physicist by training, Jardine is at 29 the youngest person ever to head a government department in South Africa. But he faces the formidable task of directing a ministry beset by both political problems and decreasing funds.

Jardine says that the government plans to carry out a review of the activities of each of its seven science councils, as well as the National Accelerator Centre, the focus of recent controversies about government support for nuclear research (see Nature 365, 776; 1993). The review will take place over the next 18 months in conjunction with a research foresight study loosely modelled on Britain's technology foresight exercise.

But Jardine acknowledges that the most pressing problem facing South African science is a lack of funds. The science vote has been reduced by 27 per cent in real terms since 1987 , and is likely to drop another four per cent in next year's budget.

Jardine left Johannesburg in 1986 to study at Haverford College in Pennsylvania, before completing a master's degree at Wayne State University in Michigan. $\mathrm{He}$ returned to South Africa in 1992 as co-ordinator of science and technology policy in the ANC's department of economic planning.

His new post will give him an opportunity to help put into practice some of the ideas developed previously within the ANC, eventually leading to a restructuring of the South African science system. But he faces an uphill task. Although the minister responsible for Jardine's department, Ben Ngubane, has protested over the decline in funding for research and development, he appears to lack the influence within the cabinet to resist the cuts.

Furthermore, despite the new government's commitment to transparency, Ngubane has declined to make public the recommen-

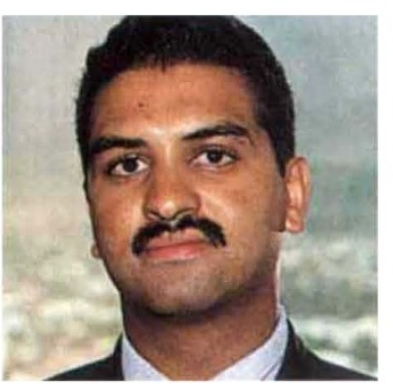

Jardine: facing tight funding and political challenges an interim body, and the procedure by which it is to make its recommendations has yet to be determined.

In terms of special initiatives, Jardine says there are two priorities for South African research and development: finding new ways of using technology to boost economic development and of enhancing the standard of living in the rural areas.

He must first organize his new department, which has been unable to run efficiently owing to lack of staff. It has inherited some officials from the former Department of National Education, and others from the Department of Trade and Industry. But 62 posts, including almost threequarters of top management positions, remain vacant.

But Jardine's most unenvidations of his advisory committee on the allocation of the vote among the councils for the next financial year. The former government's Scientific Advisory Committee was heavily criticized for keeping its recommendations to the government secret (see Nature 362, 384; 1993).

Ngubane announced at a press conference earlier this week that a National Council for Science and Technology will be established by June. It will replace the advisory committee, which was intended only as able task is to address the department's political difficulties. The deputy minister, Mrs Winnie Mandela, appears to have escaped being fired by her estranged husthe resignation of 11 members of the executive committee of the ANC Women's League, which she heads. If she rides out this particular political storm, Jardine's most difficult challenge will be to guide her and Ngubane along a common path .

Michael Cherry band, Nelson Mandela, last week, following

\section{Australian researchers hold government to its promises}

Sydney. Biomedical researchers are putting pressure on the Australian government to honour an election promise made by the prime minister, Paul Keating, in 1993 that he would increased research grants by an additional \$A200 million a year.

Scientific bodies, frustrated by lack of action on the promise made during a hardfought election campaign, have been lobbying government ministers through reports, meetings and briefings on the state of biomedical research.

So far, however, the lobbying has been kept deliberately low-key. "We were told it might well be counter-productive to lobby too hard," said Fiona Stanley, director of the Institute of Child Health Research at the Princess Margaret Hospital for Children in Perth, Western Australia.

"We were told that the people in Canberra considered researchers to be greedy, ungrateful people who would just keep on asking for more money," said Stanley, who is convenor of an independent working group of researchers that prepared a report on the issue and briefed Keating two months ago.

Whatever the view held by federal politicians of medical researchers, Stanley and other biomedical scientists believe strongly that the government should meet an election promise to boost spending on health research to 2 per cent of the total health budget by the year 2000 .

The precise target is still being debated. But biomedical scientists understood the promise to be based on statistics produced by the Australian Institute of Health and Welfare, which showed that current spending on research was around 1.4 per cent of the total. So far, the government has increased funds distributed by the National Medical and Health Research Council (NMHRC) by only a token amount.

Ian McCloskey, director of the Prince of Wales Medical Research Institute in Sydney, New South Wales, says researchers fear that, if the government does not increase research funds in the next federal budget, due be decided over the next few months, they are unlikely to see any additional funds.

But the costs will be high. Stella Clark, president of the Australian Society for Medical Research (ASMR), which represents 9,000 researchers, says that in order to honour its promise, the government needs to add an extra $\$ \mathrm{~A} 40$ million a year to the
NMHRC's research budget for each of the next five years.

In a report recently prepared by the ASMR, and submitted to the Australian cabinet, the society says that institutional support for health and medical research and development is in long-term decline at both federal and state levels, the first affecting universities and the second hospitals.

It also claims that, in comparison to other advanced countries, Australia has a "weak track record" for individual philanthropy and corporate support of research in the public interest. As a result, many Australian researchers have been living on short-term grants of between one and three years, and have had to spend too much time seeking support for jobs that remain badly paid.

Early in 1994, Senator Graham Richardson, the former minister for health and a powerful figure in Australia's Labor government, claimed that the required extra funding being sought by the biomedical community had been locked in place. But since his retirement nothing has happened, despite a declaration of support for the funding increase from the present health minister, Carmen Lawrence. Mark Lawson 